\title{
DISLOYAL COMMERCIAL COMPETITION AND THE JURISDICTIONAL RESPONSIBILITY IN THE ROMANIAN AND E.U. LAW SYSTEM
}

\author{
Țuțuianu Ion, Lecturer $\mathrm{PhD}$ \\ UNIVERSITY OF BACĂU
}

\begin{abstract}
:
The esential element of market economy is competition. Foresights of comercial competition are also included in the treaties made with third party states, which are not part of the EU. Besides that, Romania has taken over several firm obligations regarding competitional policies, even by common European agreement on the $1^{\text {st }}$ of February 1993. In this agreement, the progressive elimination of discrimination between romanian economical agents and commons is being provided for, in matters of supplying and distribution conditions of merchandise. This is one of the few things solved regarding this chapter.
\end{abstract}

\begin{abstract}
For the existence of a functional market economy, an undistorted competitional environment remains the main condition, beside the freedom for mobility of merchandise, persons, services and capital. Respecting the standards of the competition ensures economical progress, protection of consumer interests and enables competition of products and services."
\end{abstract}

Any contrary action towards honest usability in industrial activity and commercializing of products, procedure of work or performing services is by definition called non-legal commercial competition ${ }^{2}$, being in contradiction with the honest competition, being understood as the unconfined battle between businessmen, fought with honest ways - meaning to use those rules which although lead towards the elimination of a merchant from the market, are based on legal methods that offer advantages in price, quality, modernity or utility for commercial clients. ${ }^{3}$

The Romanian law system stipulates this aspect of jurisdictional responsibility for neglecting the rules and principles of honest competition way before adhering to the European Union. In 1968 the Romanian government has ratified the Convention of Paris for industrial property protection from the $20^{\text {th }}$ of March 1883 and revised in

\footnotetext{
${ }^{1}$ See Aurelia Cotutiu-Georgeta Valeria Sabau,

${ }^{2}$ Legea nr. 11/1991art.2

${ }^{3}$ See O. Manolache, Regimul juridic al concurentei in dreptul comunitar, editura ALL, Bucuresti, 1997.
}

Stockholm $1967^{4}$. This one is better known under the name of The Union Convention of Paris (Conventia de Uniune de la Paris). The state of Romania has adhered to the Convention of Paris in October the $6^{\text {th }} 1920$, the ratification being done on March the $13^{\text {th }}$ 1924. The ratification made in 1968 was the result of the revision of the 1967 convention, by respecting the rule of ratification for each amendment that was to come. Another important international contract in this matter is The General Agreement on Tariffs and Trade (GATT) signed at Geneva 1947 and entered into force on the $1^{\text {st }}$ of January 1948. The aim of this agreement is basically to regulate the dumping and the subventions for export trade. The regulations of the GATT where completed by adopting the Antidumping Code, with a last amendment at Geneva, $12^{\text {th }}$ of April 1979. The Romanian government became a member of the GATT agreement in 1972 and ratified it in 1972. The Anti-dumping Code was ratified in 1980. Furthermore we have to state that on the $12^{\text {th }}$ of April 1979 there has also been signed the Anti-subvention and counterbalance measures Code $^{5}$, but which Romania did not sign, taking into account the political and economical system during that time.

\footnotetext{
${ }^{4}$ Decretul nr. 1177/1968, in Buletinul Oficial nr. 1 din 6 ianuarie 1969 - decree $\mathrm{nr}$ 1177/1968, in Official Journal nr. 1 from January the $6^{\text {th }} 1969$

5 Titus Prescure, Curs de dreptul concurentei comerciale, Editura Rosetti, 2004, p. 33-34; Aurelia Cotutiu-Georgeta Valeria Sabau, op. cit. p. 58-60
} 
But the Romanian constitution also stipulates the government's obligation towards providing protection of loyal competition. $^{6}$ The 1991 Constitution stipulated that "Romania's economy is a market economy"7, and the Constitution from 1993 maintains the same concept but under the following formula:

"1. Romania's economy is a market economy, based on free initiative and competition.

2. The government has to provide:

a) freedom of trade, protection of loyal competition, the making of a favorable environment for developing the factors of production;

b) protecting national interests in economical, financial and currency related activities;

c) stimulation of national scientific and technological research, of art and copy right protection;

d) exploitation of natural resources, in agreement with national interest;

e) rebuilding and protecting the environment, as well as maintaining the ecological balance;

f) creating the necessary conditions for a better living;

g) setting in progress of regional development policies in agreement with the objectives of the European Union".

Because the negotiations for Romania's adhering to the European Union where already going on, the constitutional specification became mandatory, taking into

\footnotetext{
${ }^{6}$ Art. 135 , alin.2, lit. a

${ }^{7}$ Art. 134 of the 1991 Constitution had the following content:
}

1. Romania's economy is a market economy

2. The government had to provide for:

a. Freedom of trade, protection of loyal competition, the making of a favorable environment for developing the factors of production.

b. Protecting national interests in economical, financial and currency related activities;

c. Stimulation of national scientific research;

d. Rebuilding and protecting the environment, as well as maintaining the ecological balance;

e. Creating the necessary conditions for a better living. account the European integration at the end of article nr. 135.

Comparing to what was used to be constitutional term of Romanian economy under the communist regime, the 1991 constitution clearly stated the splitting from the centralized and statist economy system, the way the communist constitutions from $1948^{8}$ and $1965^{\circ}$ where mentioning, and the 2003 constitution made an important step towards consolidating the vision of free economy in agreement with the economy policies of the European Union.

It was exactly the Union Convention from Paris that in art. 1 forces the member countries towards repression of disloyal

\footnotetext{
${ }^{8}$ The first communist constitution stated in art. 5: "the national economy of the People's Republic of Romania includes three social and economic formations: the socialist formation, the small productions of merchandise and the private-capitalist formation. Art. 6. The basis of the social and economical socialist formation is the socialist property over the production ways, which either embodies the shape of the states property (common wealth of the people), or the shape of the cooperative-collectivist property (the collective farm property or the co-operative farmer organizations).

In the national economy system exploitation of human beings by human being is liquidated.

The socialist system, to whom the lead in the national economy of the Peoples Republic of Romania belongs, is the basis for the development of the country on the way of socialism. The state of people's democracy, proclaiming the construction of socialism as it's main duty, continuously enforces and spreads the socialist formation, and provides the uninterrupted growth of material well being, cultural level of working class people. Art. 13. The economical life of the People's Republic of Romania develops according to the governments plan of national economy, in the interest of building socialism, uninterrupted growth of material and cultural well being of working class people, enforcement of the national independency of the country and defending ability. Art 14. In the People's Republic of Romania, external commerce is a state monopoly".

9 The second communist constitution stated the same concepts, with a more emphasized formulation. Art. 5. "The national economy of Romania is a socialist economy, based on socialist property over the means of production.

In The Peoples Republic of Romania, exploitation of human beings by human being is forever cancelled and the socialist principle of repartition by quantity and quality of labor is being carried out instead.

Labor is an honorable duty for every citizen of the country."
} 
competition and towards providing effective protection for the citizens, against disloyal competition, stating in art. 10 and a half $\S 2$ that market economy is a general function of the state, and an act of disloyal competition means any act within industrial or commercial matter done without honest ways.

The convention foresees an obligation towards member countries "to provide the citizens of the union an effective protection against disloyal competition" and to forbid through internal measures any deeds that may disrepute the industry, products, industrial or commercial activity of a competitor, false statements that can disrepute the industry/enterprise, the products, the industrial or commercial activity of a competitor, as well as the indications or statements which could be, by being used in practice for commerce, susceptible to confusing the public mass regarding the origin, way of fabrication, characteristics, abilities or quantity of goods. Therefore, the member state of the Convention is obliged to legally regulate the elimination of disloyal competition, as well as whatever may distort it from it's licit purpose. (art. 10 and a half $\S$ $1)$.

Other countries have also implemented regulations concerning disloyal competition. In Germany for instance, where the old civil code was regulating the responsibility for damage, came up a special law in 1896 for repressing disloyal competition, in 1909 coming a new one, this time for fighting disloyal competition. This law received amendments in 1965 and 1969, and on the $1^{\text {st }}$ of March 1992 it has been legislated for being spread in the whole country. ${ }^{10}$ It was exactly in the first article where the German law stated that "anyone who may carry out an act of dishonest competition during commercial interactions, can be forced to end those and pay for damage."

France and Italy do not have a special law regarding disloyal competition. Judgment of such acts in these countries is being done according to the common right towards misdemeanor liability on civil level, to which

\footnotetext{
${ }^{10}$ Yolanda Eminescu, Concurența neleală. Drept român şi comparat, Ed. Lumina Lex, Bucureşti, 1995, p. 4
}

the stipulations of penal law, as well as various dispositions concerning objects of industrial property. Neither England does have any special law against disloyal competition. Such acts are being judged by the penal law, and in the contrary, norms regarding liability for illicit acts are being applied. ${ }^{11}$

Starting with the political and economical changes in east-European countries through the fall of communist regimes, it had been imposed that on this side of the continent there should also be new regulations regarding competition, meaning that those countries' statist economy should also accommodate to free market economy. Poland was the first post-communist country to adopt a law concerning monopoly practice on the $24^{\text {th }}$ of February 1990 , being inspired from the German legislation. In Hungary, on the $5^{\text {th }}$ of December 1990, the law concerning interdiction of disloyal commercial deeds appeared, which replaced the communist law from 1984, and Bulgaria has adopted the law regarding protection of competition on the $2^{\text {nd }}$ of March 1991, which clearly aimed at the disloyal competition. Czechoslovakia also adopted in 1991 the law concerning the protection of economical competition, and the commercial code was completed. ${ }^{12}$

Romania used to have a tradition regarding the legislation of dishonest competition, which had only been interrupted by the communist legislation. The first norms that could serve as a support towards liability concerning the commercial competition right, where stated in the civil Code from 1865, art. $998^{13}$, considered to be the foundation of civil misdemeanor liability, as a liability of common right. In agreement with the statements of this article, misdemeanors and quasi-misdemeanors regarding commercial competition where sanctioned and the damage was solved, as to the specific misdemeanor regulations. It has been stated about this

\footnotetext{
${ }^{11}$ Ibidem, p. 5-17

12 Ibidem, p. 17

13 Any deed of a person that may cause prejudice to another, forces the one who made the mistake to fix it. This was only the translation of art. 1382 from the French civil Code: „Tout fait quelconque de l'homme, qui cause a autrui un dommage, oblige celui par la faute duquel il est arrivé, a la réparer ».
} 
doctrinarian system that it "has the shortcoming that it had to apply, with an extensive interpretation, the general rules of the liabilities born through misdemeanor and quasi-misdemeanor, the practice of competition as a phenomenon with economical preponderancy, to which its particularities are not reducible to the jurisdictional treatment that occurs to the civil illicit deeds. ${ }^{14}$ This legislation though, was to be enriched on this subject matter in 1984, by the law for itinerant commerce, in 1932 with the disloyal competition law, which had confusion and indication of false origin as a primary act of disloyal competition, and in 1937 with the decree for regulation and control over the cartels, through which measures of origin where being regulated, dedicated to stop monopoly agreements. ${ }^{15}$

Starting with the political and economical changes from 1989, constitutional and legislative measures where being imposed in this subject matter as well, meant to direct the free competition intercourses towards normality and honesty. This is how normative documents were made main and usual in commercial competition's area. Law no. $12 / 1990$ pointing towards the protection of the population against illicit commercial activity, law that was republished in 1991 modified and completed. Law no. 15/1990 regarding state's economic unities reorganizations as autonomous entities and commercial corporations; Law no. 26/1990 regarding commerce's register with ulterior changes and add-inns; Law no.31/1990 regarding commercial corporations with ulterior changes and fill-inns. Law no. $11 / 1991$ regarding the disproof of unfair competition, modified through Law 298/2001; Law no.64/1991 regarding invention license. Law no. 129/1992 regarding industrial drafts and draw's protection; the Government's Ordinance no.228/1992 regarding the protection of national producers and the intern market of disloyal competition that results from the import of some products at a dumping or subsidized price as well as the

\footnotetext{
${ }^{14}$ Octavian Căpățână, Dreptul concurenței comerciale. Concurența onestă, Editura Lumina Lex, Bucureşti, 1992, p. 30

${ }^{15}$ Ibidem, p.31
}

export at lower price than the one on the internal market, as well as the commune Commands of the Finance and Commerce's Departments no. 127/1992 and no.128/1992 emitted in the application of the Government's Ordinance no. 228/1992, Law no. 21/1996 regarding competition modified through Government's Emergency Orderly no. 121/2003 approved its self through low no. 184/2004; Law no. 31/1996 regarding state's monopoly; Law 84/1998 referring to brand's and geographic indications Law no. 143/1999 regarding public assistance modified and completed through Law no. 603/2003; Law no. 148/2000 regarding advertising modified and completed through Law no. 283/2002.

It must be mentioned that the presented normative paper's list that contains targets regarding commercial competition is complete and finally in that number of normative papers that regard settlements in competition's area is on the increase, especially that our country has engaged to adopt normative paper packets that will make it compatible with the European Union's directive and legislation regarding the competition area. It must be mentioned that not all the normative papers that contain targets regarding competition's settlements refer exclusively to this problem, but the targets are dispersed in more normative papers that have as the central goal other subjects than competition ${ }^{16}$.

In Romania the intern justice paper that clears the dumping and export's subsidies problems is the Government's Ordinance no.228/1992 regarding the protection of national products and the intern market of the unfair competition resulted from the import of products at a dumping or subsidies price as well as the export at prices lower than on the internal market, paper that clears: repressing measures of the unfair competition at the export and import as well as safeguarding measures of the national interests regarding the import of subsidies products, dumping prices, than measures to prevent the complains from the countries where Romania exports products regarding

${ }^{16}$ Titus Prescure, op. cit., p. 32 
dumping prices as well as the contravention sanctions that can be applied for the commitment of disloyal competition's facts. The same paper was creating the Import and Export Supervise Department that has a department for other dumping taxes, compensatory taxes and safeguarding measures, and a Prices department.

According to the Constitution's statements, the multilateral conventions had became intern right that Romania had adhered or ratified in competition's area as the European Agreement by Romania's association at the European Community and associated states ratified it through Law no. 20/1993. The interim agreement referring to commerce and facts was related with the commerce between Romania, the European Economic Community and the Coal and steel's Economic Community ratified through low no. 16/1993 as well as the Agreement between the states members of the Free Exchange European Association (FEEA) and Romania, ratified through low no. $19 / 1993^{17}$.

The aim of anti dumping laws is to protect the national industries from the effect of lower than normal value prices for import. The main substation of the necessity of antidumping settlement is that the foreign producers can use selling at high prices on the international protected markets to counterpoise small prices made exports against other market's competition although this practice is considered against the competition and is sanctioned by Law no. 21/1996. The anti-dumping settlements follow to avert this danger by establishing an accessory tax for the imports in the dumping regime at the price difference between the export price and the natural value of the product $^{18}$.

If the Romanian's economical politics legislation including the commercial competition has agreed with the European's Union legislation in the area or is considered to harmonize this legislation, all is in concordance with the constitutional conditions regarding the integration into the European Union from article 148: "1 The adhesion of Romania at the organic

\footnotetext{
${ }^{17}$ Octavian Căpățână, op. cit. p. 27-28

${ }^{18}$ Titus Prescure, op. cit. p. 131-132
}

conventions of the European Union, with the aim of transferring some attributions to the common institutions as well as exert with the other member states of the competences stated into this convention, it's made through the law adopted into the common conference of the Deputy Chamber and the Senate with a majority of $2 / 3$ from all the deputies and senators. 2. Pursuant the adhesion the foresights of the constitutive conventions of the European Union as well as other common settlements having an imperative character are preferential towards the contrary stipulations from the internal law system to comply with all of the adhesion conditions. The statements of paragraph 1 and 2 are applied adequate for the reviewed papers of the organic conventions of the European Union as well.

The Parliament, Romania's President, the Government and the Judiciary guarantee the fulfillment of the obligations that result from the foresights of the adhesion convention and paragraph's 1 and 2. 5. The Government passes on to the two Chambers of the Parliament the drafts of the imperative papers before this are submitted to be approved by the European Union's institutions."

Although Romania's Constitution forecasted these things since 2003 it's known that the talks of Romania's adhesion of the European Union were advanced but not final $^{19}$ and the law system was already adapted to the European adhesion, Romania legislatively acting like a common country. It must be remembered that the Convention for establishing an European constitution concluded between the member states Government's conference officials from October 26, 2004 although it's ratification through referendum or congressmen votes was difficult, it had Section 5, rules regarding competition (art. III, 161-166) ${ }^{20}$, Subsection 2 , Helps given by member states (art.III, 167$169)^{21}$.

Rules of the common Convention regarding competition are a corollary of the common stipulations referring to free

\footnotetext{
19 To look at Tratatul privind aderarea României la Uniunea Europeană, Editura All Beck, Bucureşti 2005

${ }^{20}$ Ibidem, p. 454-456

${ }^{21}$ Ibidem, p. 456-458
} 
circulation of products so the aim of the stipulations is to assure a free competition that promotes free circulation of products and stop restriction regarding common market's functioning that can affect the commerce between member states, general inters of corporations and consumers. Rules regarding competition are original in the stipulations that refers at the accomplishment of an internal market characterized by removing obstacles in free circulation of products, persons, jobs and capitals between member states, a regime that guarantees the integrity of competition, approachment of national legislation necessary for the well function of the common market. The members of the European Union have the obligation, in the making of the common objectives, that their action for setting the economical rules should adapt to the principle of an open market economy in which competition is free. Any norms aiming to stop, restrict or denaturate competition, may result in a malfunctioning common market or creating discontinuation in the intra-common relationships that are conceived and adapted towards satisfying a market economy. If the European Union finds that a difference between the settled agreements through law, rules or administrative action from a member state misrepresents the terms of competition in the common market and that misrepresentation has to be eliminated, proceeding by consulting the member states, and if this consultation is not closed by an agreement of elimination of the respective misrepresentation, the Council of the European Union decides for the necessary directives, and the Comission, joined by the Council of the European Union can take any measure present in the European Union Treaty. $^{22}$

The main content of the commercial competition in the European Union can be found in Title VI. Common Norms concerning competition, fiscality and approach of legislation (chapter 1.Rules of competition, art. 81-89) of the Treaty

\footnotetext{
22 Also see Octavian Manolache, Drept comunitar, ediţia a IV-a, Editura All Beck, p. 296-398
}

establishing the European Community. ${ }^{23}$ Article 81 of the Treaty declares interdicted as incompatible with the common market all the agreements between enterprises, decisions made between asociates of enterprises and concentrated actions that may affect commerce between states and that result in stopping, restriction or distortion of competition within the common market, especially those that: directly or indirectly settle the selling or buying prices or any other commercial conditions; limit or control production, market technical evolution or investments; spread the markets or supplying sources; apply some different conditions to equivalent transactions with other commercial partners, this way placeing them in a competitional disadvantage; make agreements upon contracts depending on the acceptance from the other part of some extra obligations, which throught their nature, or by commercial habits, don't have anything to do with such contracts. The following paragraph stipulates that any agreements or decisions forbidden by the first paragraph have zero rights to exist. Same goes for paragraph 3, that declares the statements from the first paragraph as inaplicable in the following cases: to any agreement, agreement category or enterprise; to any concentrated actions or category of concentrated actions, that contributes to perfection of production, distribution of goods or to promovation of technical and

\footnotetext{
${ }^{23}$ The actual text is in fact the strengthened text of the Treaty establishing the Economic European Community, signed in Rome, $25^{\text {th }}$ of March 1957, set into force on $1^{\text {st }}$ January 1958 . The treaty was amended by the Single European Act , 17-28 of February 1986, through the Treaty concerning the European Union at Maastricht on the $7^{\text {th }}$ of February 1992, by the Treaty from Amsterdam $2^{\text {nd }}$ of October 1997, as well as by the Nisa Treaty from the $26^{\text {th }}$ of February 2001, that amends the Treaty concerning the European Union, the institutive treaties of the European Communities and certain auxiliary acts. See the Romanian text of the Treaty establishing the European Union in "Documente de bază ale Comunităţii şi Uniunii Europene, ediţia a II-a coordonată de Valentin Constantin, Polirom, 2002, p. 17- 148" off the Treaty concerning the European Union (the Maastricht Treaty), p. 153-194, and of the Amsterdam Treaty, p. 197-199, as well as the internal Regulation of the European Unionn Council from the 31st May 1999, p. 203-216, of the internal Regulation of the European Community Comission from the 29th of November 2000, p. 219-228.
} 
economical progress, as long as an equitable part of the resulting benefits will be allocated to the consumers, and which: don't force the related enterprises any restrictions that are not esential to creating objectives; that don't give such enterprises the option to eliminate competition regarding a substantial part of the discussed products.

From the analysis of the mentioned article it can be concluded that stopping, restriction or distortion of the competition, a necessary condition of the commerce affection from the member states, and not an effect, especially because the ways of the agreements, decisions or actions are indicated. Therefore, as a result, the rule is one of the development of some fair jurisdictional relationships within the commercial circuit. The vast majority of the agreements, decisions or actions don't tend to restrict competition, without even being necessary to apply the mentioned exceptions.

For antisocial deeds stated within the legislation of competition, contraventional liability has been implemented, beside the patrimonial liability, through Law no. 11/1991, Government's Ordinance nr. 2/2001 and Law no. 268/2002. The disluyal competition offence results in penal liability for the perpetrator, to whom, beside the special dispositions, can be applied the disopsitions of the penal procedure Code. Penal and contraventional liability for the same deed are excluded, yet can civil action in disloyal competition coexist with administrative and penal liability.

\section{References:}

[1] Prescure T., Curs de dreptul concurenței comerciale, Editura Rosetti, 2004;

[2] ManolacheO., Manolache O., Regimul juridic al concurenței în dreptul comunitar, Editura ALL, Bucureşti, 1997;

[3] Eminescu Y., Concurența neleală. Drept român şi comparat, Ed. Lumina Lex, Bucureşti, 1995

[4] Cotuțiu A, Sabău G.V., Drept român şi comunitar al concurenței;

[5] Vasilescu B., Concurența neloială sancționată de Legea nr.11/1991, în Revista de drept comercial, nr.10/2007. 